\title{
URINER INCONTINENCE SCREENING INVOLVING 6957 MIDDLE SCHOOL STUDENTS IN THE ESKISEHIR PROVINCE
}

\author{
AYFER ACIKGOZ ${ }^{1}$, Mukaddes Baskaya ${ }^{2}$, Merve Cakirli ${ }^{3}$, Fatih Cemrek ${ }^{1}$, and Baran \\ Tokar $^{4}$ \\ ${ }^{1}$ Eskisehir Osmangazi University \\ ${ }^{2}$ Gazi University \\ ${ }^{3}$ Affiliation not available \\ ${ }^{4}$ Eskisehir Osmangazi University Medical Center
}

April 16, 2021

\begin{abstract}
Aim: Urinary incontinence is an important problem that can arise due to neurogenic or functional reasons and can negatively affect the psychological, social and personality development of children. This study was conducted in Eskişehir province, on secondary school students in order to determine the prevalence and nature of urinary incontinence at night and/or daytime. Methods: The study universe included all secondary school students attending state elementary schools in the city center of Eskişehir $(\mathrm{N}=34.000)$. Ethics Committee and Provincial Directorate of National Education approval was obtained before conducting the study, which was supported by Eskişehir Osmangazi University Scientific Research Projects Commission (20171876). A data collection form prepared by the researchers, and a consent form were delivered in sealed envelope to the parents via the students. The study data were collected between 09.05.2018-30.05.2018. Only volunteers were included in the study. 6957 questionnaires which have been fully completed from the 7370 surveys have been taken into consideration. The statistical analysis was carried out using the SPSS soft ware package. Results: The number of children found to have urinary incontinence was determined to be 215 (3.1\%). It has been determined that 33 children (0.5\%) have urinary incontinence only at daytime, 61 children $(0.9 \%)$ have urinary incontinence both at night and daytime, and 121 children $(1.7 \%)$ have urinary incontinence only at night. It was observed that $56 \%$ of the children suffering from urinary incontinence had not applied to any health institution for treatment before. Conclusions: Children and families with urinary incontinence need medical information and support to cover the cause of the problem and suggestions for solutions. Accompanying pathologies in cases to be detected can be determined in the early period by means of school screenings and medical evaluation and support can prevent the psychosocial and personality development of children from being adversely affected.
\end{abstract}

\section{URINER INCONTINENCE SCREENING INVOLVING 6957 MIDDLE SCHOOL STU- DENTS IN THE ESKISEHIR PROVINCE}

\section{ABSTRACT}

Aim: Urinary incontinence is an important problem that can arise due to neurogenic or functional reasons and can negatively affect the psychological, social and personality development of children. This study was conducted in Eskişehir province, on secondary school students in order to determine the prevalence and nature of urinary incontinence at night and/or daytime.

Methods: The study universe included all secondary school students attending state elementary schools in the city center of Eskişehir $(\mathrm{N}=34.000)$. Ethics Committee and Provincial Directorate of National Education 
approval was obtained before conducting the study, which was supported by Eskişehir Osmangazi University Scientific Research Projects Commission (Project no: 2017-1876) . A data collection form prepared by the researchers, and a consent form were delivered in sealed envelope to the parents via the students. The study data were collected between 09.05.2018 and 30.05.2018. Only volunteers were included in the study. 6957 questionnaires which have been fully completed from the 7370 surveys have been taken into consideration. The statistical analysis was carried out using the SPSS soft ware package.

Results: The number of children found to have urinary incontinence was determined to be $215(3.1 \%)$. It has been determined that 33 children $(0.5 \%)$ have urinary incontinence only at daytime, 61 children $(0.9 \%)$ have urinary incontinence both at night and daytime, and 121 children $(1.7 \%)$ have urinary incontinence only at night. It was observed that $56 \%$ of the children suffering from urinary incontinence had not applied to any health institution for treatment before.

Conclusions: Children and families with urinary incontinence need medical information and support to cover the cause of the problem and suggestions for solutions. Accompanying pathologies in cases to be detected can be determined in the early period by means of school screenings and medical evaluation and support can prevent the psychosocial and personality development of children from being adversely affected.

Keywords: Urinary incontinence, children, school screenings

\section{What is already known about this topic?}

Urinary incontinence is an important problem that can negatively affect the psychological, social and personality development of children. Despite this, many families do not apply to a health institution because of the expectation that it will pass by itself and because they accept it as a situation to be ashamed of and hidden. It is important to identify the children who do not apply to the health institution.

\section{What does this article add?}

Thanks to the study, it was identified 120 (56\%) children that had not been taken to any health institution before due to this problem. These children were directed to treatment. This situation shows the importance of school screenings. The finding of children who did not improve despite treatment was also an important result in the study. Also, the study showed that the parents still used the punishment method.

\section{INTRODUCTION}

Urinary incontinence is a common problem in childhood that can occur due to neurogenic or functional reasons (1). According to the new terminology suggested by the International Child Continence Association (ICCS), incontinence is divided into two groups as continuous and intermittent incontinence. While enuresis in the intermittent incontinence group only means incontinence during sleep (2), the term "daytime incontinence" is used for children who do not have urinary incontinence during the night and who have urinary incontinence during the day only (3). For these definitions, the child must be over 5 years old and have involuntary incontinence for at least 3 months and at least twice a week without any central nervous system defects $(4,5)$.

Urinary incontinence is a condition that negatively affects the quality of life and can cause psychosocial problems in both the family and the child (6). It can cause adaptation problems, social exclusion, low self-esteem, and decrease in school performance in children (7). It may cause the child's relationship with the family to deteriorate, the family to blame and punish the child, and to restrict their activities $(8,9)$. Despite this, many families do not apply to a health institution because of the expectation that it will pass by itself and because they accept it as a situation to be ashamed of and hidden (10). Lack of a standard screening program for the detection of urinary incontinence in our country also delays the diagnosis (11).

In this study, it was aimed to determine the children with urinary incontinence problem at a state secondary school in Eskişehir city center, and to evaluate the relationship between urinary incontinence and the social and medical anamnesis of the child. After the study was completed, families that had urinary incontinence problems and made a request were informed and directed for appropriate treatment. 


\section{METHODS}

\section{Samples}

All of the students of the secondary school that is affiliated to the state in Eskişehir city center were included in our study $(\mathrm{N}=34.000)$. Incomplete questionnaires and children diagnosed with neurogenic bladder were excluded from the study. Of the 34,000 questionnaires distributed, 7370 were sent to us, and the study was completed with 6957 people.

\section{Materials}

In order to collect the data in the study, a data collection form prepared by the researchers in line with the literature was used. The data collection form includes questions that question the descriptive characteristics of students and their voiding disorders. For the content validity of the questionnaire, expert opinions were taken from a total of six people, one of whom was a pediatric nursing specialist, four of them pediatric urologists, and one of whom was a statistician. The questionnaire items were prepared in line with the recommendations.

\section{Prosedure}

Before the study was carried out, the permission of the Ethics Committee and the Provincial Directorate of National Education was obtained, and it was supported by the Scientific Research Projects Commission of Eskişehir Osmangazi University as the project numbered 2017-1876. The study data was collected between 09.05.2018 - 30.05.2018. The purpose of the study was explained to the teachers. The questionnaire and consent form were delivered to the families by the teachers in a sealed envelope. The questionnaires filled out by the parents were also delivered to the teachers in a sealed envelope.

In our study, it was stated at the end of our questionnaire that referrals for treatment can be made to the families who request, if they write their contact information. At the end of the study, the families were called by phone and a meeting day was determined, and the families attending the meeting were informed and directed for diagnosis and treatment.

\section{Statistical Analysis}

Statistical analyses were performed using the SPSS software (IBM Corp. Released 2012. IBM SPSS Statisticsfor Windows, Version21.0. Armonk, NY: IBM Corp.). Percentage and chi-square tests were used to evaluate the data, $\mathrm{p}<0.05$ was considered significant.

\section{RESULTS}

The study was completed with 6957 people. The ages of the children included in the study are between $10-15$ and the average age is 11,9 . It was found that 215 of the children $(3.1 \%)$ had urinary incontinence problems. 33 of these children (0.5\%) leak urine only during the day, $61(0.9 \%)$ both during the day and at night, and $121(1.7 \%)$ only at night. Table 1 shows the relationship between the descriptive characteristics of the child and the problem of urinary incontinence. There is a relationship between age, school success, the age of starting toilet training and urinary incontinence problem $(\mathrm{p}<0.001)$.

The relationship between the child's health history and urinary incontinence problem is evaluated in Table 2. The problem of urinary incontinence was found at a significantly higher rate in children with a history of urinary tract infection or constipation, surgery, chronic disease or psychological disorders $(\mathrm{p}<0.001)$.

In our study, 1621 of the children have a history of surgery. 489 of these are adenoid vegetation surgery. 586 of the children have a diagnosed chronic disease and the most common diagnosis is asthma $(n=117)$. The number of children with diagnosed psychological diseases is 104 and the most common diagnosis is attention deficit-hyperactivity disorder $(\mathrm{n}=57)$.

The relationship between some characteristics of the family of the child and the urinary incontinence problem in the child is given in Table 3. A relationship was found between income level and urinary incontinence 
problem $(\mathrm{p}<0.001)$. It was determined that there was no relationship between the number of children and urinary incontinence problem $(\mathrm{p}>0.05)$.

In Table 4, the relationship between the history of urinary incontinence of other family members and the presence of urinary incontinence in the child is given and it was determined that there is a significant relationship between them $(\mathrm{p}<0.001)$.

In our study, it was determined that $120(56 \%)$ of the children with urinary incontinence problem had not been taken to any health institution before due to this problem. $13.9 \%$ of the children who applied to health institution but still have urinary incontinence problem did not continue the recommended treatment, $11.6 \%$ continued to have urinary incontinence despite treatment, in $6.9 \%$ the severity of urinary incontinence decreased with treatment, in $7.4 \%$ urinary incontinence stopped with treatment but started again after a while.

Families were asked if there was any significant change in their lives that could effect the child before their children started to have urinary incontinence. $7.9 \%$ of the families stated that the sibling of the child was born, $2.7 \%$ stated that they moved to a new house, $3.7 \%$ stated that the parents divorced, $1.8 \%$ stated that the child was hospitalized, $2.3 \%$ stated that one of the family members got sick or was hospitalized and $1.3 \%$ stated that the child was effected by war.

In our study it was observed that some families blamed or punished their children who had urinary incontinence problem. $8.8 \%$ of the families stated the punishment they gave as "I am angry with my child, I scream", $5.1 \%$ "I state that I am angry with my body language", $6 \%$ "I say that it upsets me", $4.1 \%$ "I compare them with other children".

\section{DISCUSSION}

In our study, the prevalence of urinary incontinence was found to be $3.1 \%$, and the frequency of urinary incontinence was found to decrease with increasing age. The frequency of urinary incontinence in school-age children is stated to be $2-7 \%$ (12). The prevalence of enuresis is $15-20 \%$ on average in 5-year-old children, $5-6 \%$ in the 10-year-old group, and less than $1 \%$ in the 15 and above-year-old group $(13,14)$. Studies $(7,15$, 16) have also stated that the prevalence of enuresis decreases with increasing age. Our result is compatible with the literature. This result is thought to be due to the increase in controlling ability in children as the age increases.

In our study, it was determined that the frequency of urinary incontinence was $3.2 \%$ in boys and $3 \%$ in girls, and the relationship between them was not significant $(\mathrm{p}>0.05)$. Similarly, in the study of Kahriman and Mumcu (2011), it was found that enuresis was seen more in boys, but the result was not significant. Goksu et al. (2020), in their study with primary school children, found that the frequency of enuresis was higher in boys. Similarly, in a meta-analysis conducted with Iranian children (18), it was found that the prevalence of enuresis was higher in boys. Contrary to these results, there are also studies $(16,19)$ in which the frequency of urinary incontinence was higher in girls. It is thought that this difference in the results may be due to the lack of gender homogeneity in the studies. In the literature, it is stated that girls complete toilet training earlier than boys, and male gender is seen as a risk factor delaying toilet training (12). The reason for this is thought to be that girls develop faster than boys, as continence is associated with developmental maturity. It has been suggested that the incidence of enuresis is also less common in girls for this reason, although it has not yet been proven conclusively (20).

In our study, a significant difference was found between children's school success and urinary incontinence problem. Similar to our results, studies $(21,22)$ have also found that enuretic children have a lower school success. These results can be considered as the reflection of low self-esteem and sense of failure due to urinary incontinence problem experienced by children on school success.

In our study, a significant relationship was found between the age of starting toilet training and the frequency of urinary incontinence. Similar to our results, Barone et al.'s (2009) study also states that as the age of starting toilet training is delayed, the frequency of urinary incontinence increases and urge-type urinary 
incontinence problem is observed. Contrary to these results, Goksu et al. (2020) concluded in their study that the age of starting toilet training did not affect the frequency of enuresis. However, it was thought that this situation might be due to a random response given at face-to-face interviews with the families. In the literature (24), it has been stated that starting toilet training before the child reaches the age of 1.5 and after the age of 2.5 may pave the way for enuresis. It has been suggested that a higher rate of enuresis may be seen, especially in children who start toilet training late.

In our study, a significant relationship was found between the child's operation status, chronic illnesses, presence of psychological illnesses and their urinary incontinence problem. There are previously conducted studies that show a relationship between adenoidectomy $(25,26)$ and attention deficit and hyperactivity disorder (27), and the enuresis frequency. In addition, there are studies reporting a relationship between urinary incontinence and obesity and high body mass index $(28,29)$. Erdem et al. (2006) suggested that obesity will result in bad eating habits and constipation, and that this may be associated with urinary incontinence.

In our study, the rate of urinary incontinence was found to be significantly higher in children who had at least one urinary tract infection (UTI). Similarly, studies (30-33) have shown that there is a significant relationship between urinary tract infection and urinary incontinence problem. In addition, it has been stated that the possibility of a structural anomaly in the urinary system increases in cases with UTI with enuresis (30).

In our study, it was found that the problem of urinary incontinence was significantly higher in children with constipation. In the literature $(17,31,34)$, it has been stated that constipation is a risk factor for enuresis. This result is thought to be due to the fact that the genitourinary and gastrointestinal systems share the same embryological origin, anatomical cavity and innervation (35).

In our study, it was found that the lower the family income level, the higher the frequency of urinary incontinence. In many studies $(17,18,36,37)$, it is stated that urinary incontinence is a common pathology in children of families with low socio-economic status. This shows that economic and social problems in the family can increase the frequency of urinary incontinence by creating stress on children. In a study conducted by Erguven et al. (2004), it was found that there was no significant relationship between children with primary enuresis and the control group in terms of socio-economic and educational levels of families. However, it was stated that this result was due to the participation of people with similar socioeconomic status.

In our study, it was found that children with a history of urinary incontinence in their mothers, fathers and siblings have urinary incontinence problems significantly. In accordance with our result, it has been stated in the literature $(18,39,40)$ that genetic factors or genetic predisposition are important in the etiology of urinary incontinence problem. In the study of Akyuz et al. (2014), it was determined that $50 \%$ of the patients had a history of enuresis nocturna in their siblings, $42.1 \%$ in the mother, $28.9 \%$ in the father and $89.5 \%$ in their relatives from their mother or father's side. However, it was reported that it would be wrong to explain this situation only with genetic transmission, and the toilet training the child received and the approach of the family may also have an effect.

In our study, it was found that $56 \%$ of the children with urinary incontinence problem had not been taken to any health institution before due to this problem. In the literature (42-44), it was stated that families also did not seek treatment because they had a history of urinary incontinence, believed that it would recover spontaneously, and fear that the drugs used could cause infertility. This result showed the importance of detecting children with urinary incontinence problems by screening and the need for medical information for the families of children with problems.

In our study, some families whose children had urinary incontinence stated that they reacted as "I am angry at my child, I am shouting", "I state that I am angry with my body language", "I say that it hurts me", "I compare them with other children". In their study, Karaman et al. (2013) found that $58.1 \%$ of the families used at least one punishment method against their children with urinary incontinence problem, such as reprimanding, threatening with punishment, humiliating in the presence of others and not fulfilling their 
requests. In the study of Sarhan et al. (2021), it was stated that $47 \%$ of the families punished their children for urinary incontinence. In the study of Tabanoglu and Ozlu (2021), on the contrary to these results, $86.4 \%$ of the families stated that the child who has urinary incontinence problem at night should not be punished. In a study (47) comparing children with enuresis who were punished by their families and those who were not, it was found that depressive symptoms were significantly higher and quality of life was lower in children who were punished. In addition, it was stated that the severity of enuresis in punished children was significantly higher than in children who were not punished. Based on this result, it can be said that the punishment approach of families does not prevent urinary incontinence in children, on the contrary, it harms and increases the severity of the problem.

\section{CONCLUSION}

In our study, the number of children with urinary incontinence problems was found to be 215 (3.1\%). A significant portion of the families participating in our study did not take their children to any health institution before due to urinary incontinence problem. On the other hand, $52.5 \%(\mathrm{n}=113)$ of the families added their contact information to the questionnaire in order to get support. These results showed that patients with urinary incontinence problems and their families need medical information and support to cover the cause of this problem and suggestions for solutions. While the accompanying pathologies can be detected in cases to be detected in the early period with school screenings, it can be prevented from adversely affecting the psycho-social and personality development of children with medical evaluation and support.

\section{Importance of the Study}

In our study, it was stated at the end of our questionnaire that referrals for treatment can be made to the families who request, if they write their contact information. At the end of the study, the families were called by phone and a meeting day was determined, and the families attending the meeting were informed and directed for diagnosis and treatment. Our study is important in terms of reaching a very large population in Eskisehir Province and creating social awareness. It is also important for children with urinary incontinence problems in that they are directed to diagnosis and treatment before it is too late.

\section{Conflict of Interest Statement}

The authors have no relevant financial or non-financial interests to disclose.

\section{Authors' Contributions}

These authors contributed equally to this paper.

\section{REFERENCES}

1. Ozcetin M, Uluocak N, Yilmaz R, Atilgan D, Erdemir F, Karaarslan E. The evaluation of urinary incontinence in preschool age children. $J$ Child 2010; 10(2): 75-81.

2. Austin PF, Bauer SB, Bower $\mathrm{W}$ et al. The standardization of terminology of lower urinary tract function in children and adolescents: Update report from the standardization committee of the International Children's Continence Society. Neurourology and urodynamics2016; 35(4): 471-481.

3. Tekin A. Approach to the bedwetting child. Journal of Pediatric Surgeons 2016; 30(6): 554-558.

4. American Psychiatric Association. Diognostic and statistical manual of mental disorders Fifth Edition . American Psychiatric Pub 2013; 355-360.

5. Nevéus T, von Gontard A, Hoebeke P et al. The standardization of terminology of lower urinary tract function in children and adolescents: report from the Standardisation Committee of the International Children's Continence Society. J Urol 2006;176(1): 314-319.

6. Collis D, Kennedy-Behr A, Kearney L. The impact of bowel and bladder problems on children's quality of life and their parents: A scoping review. Child: care, health and development 2019;45(1): 1-14.

7. Ozden C, Ozdal OL, Altinova S, Oguzulgen I, Urgancioglu G, Memis A. Prevalence and associated factors of enuresis in Turkish children.Int Braz J Urol 2007; 33(2): 216-222. 
8. Karratli P, Adana F. Enuresis Frequency, Mother Attitude and Related Factors in First Class Students: Aydin Sample. Journal of Duzce University Health Sciences Institute 2018; 8(3): 123-127.

9. Tabanoglu SM, Ozlu SG. Evaluation of knowledge level and attitudes of families about enuresis nocturna. Pamukkale Medical Journal2021; 14(1): 243-252.

10. Goksu M, Ozel SK, Koc M, Kazez A. Enuresis in children of primary school age and factors affecting enuresis. Journal of Pediatric Surgeons 2020; 34(3): 85-90.

11. Carman KB, Ceran O, Kaya C, Nuhoglu C, Karaman MI. Nocturnal enuresis in Turkey: prevalence and accompanying factors in different socioeconomic environments. Urologia Internationalis 2008;80(4): 362-366.

12. Cetin N, Canoglu Z, Ozler Z, Erol K, Cilek M. Evaluation of the Factors Affecting Toilet Education and the Relationship Between Toilet Training Age and Voiding Dysfunction. Turkish Research Journal of Medical Student 2020; 2(3): 126-134.

13. Yeung CK, Sreedhar BIJI, Sihoe JD, Sit FK, Lau J. Differences in characteristics of nocturnal enuresis between children and adolescents: a critical appraisal from a large epidemiological study.BJU international 2006; 97(5): 1069-1073.

14. Avanoglu A, Baskin E, Soylemezoglu O, Tekgul S, Ziylan O, Zorludemir U. Turkey Enuresis Guide . Turkey enuresis working group 2010.

15. Karničnik K, Koren A, Kos N, Marčun Varda N. Prevalence and quality of life of Slovenian children with primary nocturnal enuresis.International Journal of Nephrology 2012; Article ID509012: 1-6.

16. Kurtuncu M, Alkan I. Enuresis nocturna prevalence and related factors in 6-12 years old children. Electronic Journal of Vocational Colleges 2016; 6(1): 33-37.

17. Kahriman I, Mumcu HK. The Prevalence and influential risk factors of enuresis in children 7-12 years of age. Journal of Continuing Medical Education 2011; 20(5): 195-201.

18. Hadinezhad Makrani A, Moosazadeh M, Nasehi M et al. Prevalence of enuresis and its related factors among children in Iran: a systematic review and meta-analysis. International Journal of Pediatrics2015; 3(6.1): 995-1004.

19. Akman R, Çam H, Şenel F, Erol A. The prevalence of nocturnal enuresis among primary school children in Duzce. Turkish Journal of Urology 2001; 27 (2): 179-183.

20. Görür S, İnandi T, Turhan E, Helli A, Kiper AN. The prevalence and risk factors of enuresis in children aged between 6 and 18 years in Hatay. Turkish Journal of Urology 2008; 34 (1): 42-50.

21. Chang S, Ng C, Wong S, Behavioural problems in children and parenting stress associated with primary nocturnal enuresis in Hong Kong. Acta Paediatrica 2002; 91(4): 475-479.

22. Bolat D, Zumrutbas AE, Acar IC, Sancak EB, Eskicorapci S, Zencir M. Prevalence and risk factors of enuresis nocturna in primary school children in Denizli. Pamukkale Tip Dergisi 2013; 6(2):82-90.

23. Barone JG, Jasutkar N, Schneider D. Later toilet training is associated with urge incontinence in children. Journal of Pediatric Urology 2009; 5(6): 458-461.

24. Ekşi, A. Ben Hasta Değilim: Çocuk Sağlı̆̆ ve Hastalıklarının Psikososyal Yönü (2 ${ }^{\text {nd }}$ Ed.). Nobel Medical Bookstores, İstanbul, 2011.

25. Weissbach A, Leiberman A, Tarasiuk A, Goldbart A, Tal A. Adenotonsilectomy improves enuresis in children with obstructive sleep apnea syndrome. International Journal of Pediatric Otorhinolaryngology 2006; 70(8) :1351-1356.

26. Acar IC, Zumrutbas AE, Eskicorapci S, Tegin C, Sinik Z, Kara CO. The effects of adenoidectomy and tonsillectomy on monosymptomatic enuresis nocturna. Pamukkale Medical Journal 2011; 4(1): 9-13.

27. Khazaie H, Eghbali F, Amirian H, Moradi MR, Ghadami MR. Risk factors of nocturnal enuresis in children with attention deficit hyperactivity disorder. Shanghai Archives of Psychiatry 2018; 30(1):2026.

28. Erdem E, Lin A, Kogan BA, Feustel PJ. Association of limination dysfunction and body mass index. Journal of Pediatric Urology2006; 2(4): 364-367.

29. Guven A, Giramonti K, Kogan BA. The effect of obesity on treatment efficacy in children with nocturnal enuresis and voiding dysfunction. The Journal of Urology 2007; 178(4): 1458-62.

30. Akbaba M, Kis S, Sutoluk Z, Kis C, Demirhindi H, Ozdener O. The prevalence and causes of enuresis 
nocturna in a regional dormitory school. TAF PrevMed Bull 2008; 7(3): 213-216.

31. Gunes A, Gunes G, Acik Y, Akilli A. The epidemiology and factors associated with nocturnal enuresis among boarding and daytime school children in southeast of Turkey: a cross sectional study. BMC Public Health 2009; 9(1): 1-8.

32. Hoebeke P, Bower W, Combs A, De Jong T, Yang S. Diagnostic evaluation of children with daytime incontinence. J Urol 2010;183(2): 699-703.

33. Dincel N, Kaplan Bulut İ, Bicer H, Mir S. Bladder dysfunctions are responsible for how much of the recurrent urinary tract infections? Turkish Archives of Pediatrics 2013; 48(2): 110-116.

34. Cayan S, Doruk E, Bozlu M, Duce MN, Ulusoy E, Akbay E. The assessment of constipation in monosymptomatic primary nocturnal enuresis.International Urology and Nephrology 2001; 3(3):513516.

35. Söderstrom U, Hoelcke M, Alenius L, Söderling AC, Hjern A. Urinary and faecalin continence: a population-based study. Acta Paediatrica2004; 93(3): 386-389.

36. Mota DM, Barros AJD, Matijasevich A, Santos IS. Prevalence of enuresis and urinary symptoms at age 7 years in the 2004 birth cohort from Pelotas, Brazil. Journal de Pediatria 2015; 91(1):52-58.

37. Solanki AN, Desai SG. Prevalence and risk factors of nocturnal enuresis among school age children in rural areas. International Journal of Research in Medical Sciences 2017; 2(1): 202-205.

38. Erguven M, Celik Y, Deveci M, Yıldız N. Etiological risk factors in primary nocturnal enuresis. Turkish Archives of Pediatrics2004; 39(2): 83-87.

39. Dallar Y, Acar BC, Kahvecioglu D, Arikan FI. The socio-demografic characteristics of enuresis nocturna in childhood. Medical Journal of Bakirkoy 2009; 5(3): 92-95.

40. Penbegul N, Celik H, Palanci Y, Yildirim K, Atar M, Hatipoglu N, Prevalence of enuresis nocturna among primary school children living in Diyarbakir. Turkish Journal of Urology 2013; 39(2):101-106.

41. Akyuz M, Koca O, Ozcan ZY, Ozturk MI, Kaya C, Karaman MI. Relationship between nocturnal enuresis and demographic structure and educational level of their families. The New Journal of Urology 2014;9(2): 6-8.

42. Oğraş MS. Wrong Beliefs and Recovery Expectations of parents of male children with nocturnal enuresis in Elazig. F.U. Journals of Health Sciences 2010; 24(3): 155-159.

43. Alparslan N, Kostak MA. Enuresis management in children. TAF Preventive Medicine Bulletin 2012; 11(5): 639-646.

44. Ozgurhan G, Sezgin B, Benzer M, Unver Korgalı E, Samanci N. Evaluation of sociodemographic factors among children with enuresis. J Kartal TR 2013; 24(2): 93-96.

45. Karaman MI, Koca O, Kucuk EV, Ozturk MI, Akyuz M. Methods and rates of punishment implemented by families to enuretic children in Turkey. International Braz J Urol 2013; 39(3): 402-407.

46. Sarhan MD, Elmeshmeshy EI, AbdelMassih A, Hassanein SA, Hasan MD. Nocturnal enuresis pattern and risk factors in the center for social and preventive medicine (CSPM), Cairo University. Middle East Journal of Family Medicine 2021; 7(10): 40-46.

47. Al-Zaben FN, Sehlo MG. Punishment for bedwetting is associated with child depression and reduced quality of life. Child abuse \& $\&$ neglect 2015; 43: 22-29.

Table 1. The Relationship Between Descriptive Characteristics of the Child and Urinary Incontinence Problem

\begin{tabular}{|c|c|c|c|c|c|c|c|}
\hline $\begin{array}{l}\text { Descriptive } \\
\text { Character- } \\
\text { istics }\end{array}$ & $\begin{array}{l}\text { Descriptive } \\
\text { Character- } \\
\text { istics }\end{array}$ & $\begin{array}{l}\text { Urinary } \\
\text { Inconti- } \\
\text { nence } \\
\text { Problem } \\
(+)\end{array}$ & $\begin{array}{l}\text { Urinary } \\
\text { Inconti- } \\
\text { nence } \\
\text { Problem } \\
(-)\end{array}$ & Total & Chi-square & $\mathrm{p}$ & p \\
\hline$\overline{\text { Age }}$ & Age & Age & Age & Age & Age & Age & Age \\
\hline $10-11$ & $\begin{array}{l}\mathrm{n} \\
\%\end{array}$ & $\begin{array}{l}119 \\
4.4\end{array}$ & $\begin{array}{l}2593 \\
95.6\end{array}$ & $\begin{array}{l}2712 \\
100\end{array}$ & 27.728 & $<0.001$ & $<0.001$ \\
\hline $12-13$ & $\mathrm{n}$ & 84 & 3298 & 3382 & & & \\
\hline
\end{tabular}




\begin{tabular}{|c|c|c|c|c|c|c|c|}
\hline $\begin{array}{l}\text { Descriptive } \\
\text { Character- } \\
\text { istics }\end{array}$ & $\begin{array}{l}\text { Descriptive } \\
\text { Character- } \\
\text { istics }\end{array}$ & $\begin{array}{l}\text { Urinary } \\
\text { Inconti- } \\
\text { nence } \\
\text { Problem } \\
(+)\end{array}$ & $\begin{array}{l}\text { Urinary } \\
\text { Inconti- } \\
\text { nence } \\
\text { Problem } \\
(-)\end{array}$ & Total & Chi-square & $\mathbf{p}$ & $\mathrm{p}$ \\
\hline \multirow{3}{*}{$14-15$} & $\%$ & 2.5 & 97.5 & 100 & & & \\
\hline & $\mathrm{n}$ & 12 & 851 & 863 & & & \\
\hline & $\%$ & 1.4 & 98.6 & 100 & & & \\
\hline Gender & Gender & Gender & Gender & Gender & Gender & Gender & Gender \\
\hline \multirow[t]{2}{*}{ Girl } & $\mathrm{n}$ & 121 & 3859 & 3980 & 0.078 & 0.78 & 0.78 \\
\hline & $\%$ & 3 & 97 & 100 & & & \\
\hline \multirow[t]{2}{*}{ Boy } & $\mathrm{n}$ & 94 & 2883 & 2977 & & & \\
\hline & $\%$ & 3.2 & 96.8 & 100 & & & \\
\hline $\begin{array}{l}\text { School } \\
\text { success }\end{array}$ & $\begin{array}{l}\text { School } \\
\text { success }\end{array}$ & $\begin{array}{l}\text { School } \\
\text { success }\end{array}$ & $\begin{array}{l}\text { School } \\
\text { success }\end{array}$ & $\begin{array}{l}\text { School } \\
\text { success }\end{array}$ & $\begin{array}{l}\text { School } \\
\text { success }\end{array}$ & $\begin{array}{l}\text { School } \\
\text { success }\end{array}$ & $\begin{array}{l}\text { School } \\
\text { success }\end{array}$ \\
\hline \multirow[t]{2}{*}{ High } & $\mathrm{n}$ & 54 & 2285 & 2339 & 69.162 & $<0.001$ & $<0.001$ \\
\hline & $\%$ & 2.3 & 97.7 & 100 & & & \\
\hline \multirow{2}{*}{$\begin{array}{l}\text { Upper- } \\
\text { middle }\end{array}$} & $\mathrm{n}$ & 79 & 3045 & 3124 & & & \\
\hline & $\%$ & 2.5 & 97.5 & 100 & & & \\
\hline \multirow[t]{2}{*}{ Middle } & $\mathrm{n}$ & 68 & 1336 & 1404 & & & \\
\hline & $\%$ & 4.8 & 95.2 & 100 & & & \\
\hline \multirow{2}{*}{$\begin{array}{l}\text { Lower- } \\
\text { middle }\end{array}$} & $\mathrm{n}$ & 12 & 65 & 77 & & & \\
\hline & $\%$ & 15.6 & 84.4 & 100 & & & \\
\hline \multirow[t]{2}{*}{ Low } & $\mathrm{n}$ & 2 & 11 & 13 & & & \\
\hline & $\%$ & 15.4 & 84.6 & 100 & & & \\
\hline $\begin{array}{l}\text { Age of } \\
\text { starting } \\
\text { toilet } \\
\text { training } \\
<1 \text { age }\end{array}$ & $\begin{array}{l}\text { Age of } \\
\text { starting } \\
\text { toilet } \\
\text { training } \\
\mathrm{n}\end{array}$ & $\begin{array}{l}\text { Age of } \\
\text { starting } \\
\text { toilet } \\
\text { training } \\
14\end{array}$ & $\begin{array}{l}\text { Age of } \\
\text { starting } \\
\text { toilet } \\
\text { training } \\
662\end{array}$ & $\begin{array}{l}\text { Age of } \\
\text { starting } \\
\text { toilet } \\
\text { training } \\
676\end{array}$ & $\begin{array}{l}\text { Age of } \\
\text { starting } \\
\text { toilet } \\
\text { training } \\
16.332\end{array}$ & $\begin{array}{l}\text { Age of } \\
\text { starting } \\
\text { toilet } \\
\text { training } \\
16.332\end{array}$ & $\begin{array}{l}\text { Age of } \\
\text { starting } \\
\text { toilet } \\
\text { training } \\
<0.001\end{array}$ \\
\hline$<1$ age & $\%$ & 2.1 & 97.9 & 100 & & & \\
\hline \multirow[t]{2}{*}{$1-3$ age } & $\mathrm{n}$ & 182 & 5828 & 6010 & & & \\
\hline & $\%$ & 3.0 & 97.0 & 100 & & & \\
\hline \multirow[t]{2}{*}{$4-6$ age } & $\mathrm{n}$ & 19 & 252 & 271 & & & \\
\hline & $\%$ & 7.0 & 93.0 & 100 & & & \\
\hline
\end{tabular}

Table 2. The Relationship Between Children's Health History and Urinary Incontinence Problem

\begin{tabular}{lllllll}
\hline & & $\begin{array}{l}\text { Urinary } \\
\text { Incontinence } \\
\text { Problem }(+)\end{array}$ & $\begin{array}{l}\text { Urinary } \\
\text { Incontinence } \\
\text { Problem }(-)\end{array}$ & Total & Chi-square & p \\
\hline History of & History of & History of & History of & History of & History of & History of \\
surgery & surgery & surgery & surgery & surgery & surgery & surgery \\
Yes & $\mathrm{n}$ & 65 & 1556 & 1621 & 5.966 & 0.017 \\
& $\%$ & 4.0 & 96.0 & 100 & & \\
No & $\mathrm{n}$ & 150 & 5186 & 5336 & & \\
& $\%$ & 2.8 & 97.2 & 100 & &
\end{tabular}




\begin{tabular}{|c|c|c|c|c|c|c|}
\hline & & $\begin{array}{l}\text { Urinary } \\
\text { Incontinence } \\
\text { Problem }(+)\end{array}$ & $\begin{array}{l}\text { Urinary } \\
\text { Incontinence } \\
\text { Problem (-) }\end{array}$ & Total & Chi-square & $\mathbf{p}$ \\
\hline $\begin{array}{l}\text { History of } \\
\text { chronic } \\
\text { disease }\end{array}$ & $\begin{array}{l}\text { History of } \\
\text { chronic } \\
\text { disease }\end{array}$ & $\begin{array}{l}\text { History of } \\
\text { chronic } \\
\text { disease }\end{array}$ & $\begin{array}{l}\text { History of } \\
\text { chronic } \\
\text { disease }\end{array}$ & $\begin{array}{l}\text { History of } \\
\text { chronic } \\
\text { disease }\end{array}$ & $\begin{array}{l}\text { History of } \\
\text { chronic } \\
\text { disease }\end{array}$ & $\begin{array}{l}\text { History of } \\
\text { chronic } \\
\text { disease }\end{array}$ \\
\hline Yes & $\begin{array}{l}\mathrm{n} \\
\%\end{array}$ & $\begin{array}{l}33 \\
5.6\end{array}$ & $\begin{array}{l}553 \\
94.4\end{array}$ & $\begin{array}{l}586 \\
100\end{array}$ & 13.795 & $<0.001$ \\
\hline No & $\mathrm{n}$ & $\begin{array}{l}182 \\
2.9\end{array}$ & $\begin{array}{l}6189 \\
97.1\end{array}$ & $\begin{array}{l}6371 \\
100\end{array}$ & & \\
\hline $\begin{array}{l}\text { History of } \\
\text { psychologi- } \\
\text { cal } \\
\text { disorders }\end{array}$ & $\begin{array}{l}\text { History of } \\
\text { psychologi- } \\
\text { cal } \\
\text { disorders }\end{array}$ & $\begin{array}{l}\text { History of } \\
\text { psychologi- } \\
\text { cal } \\
\text { disorders }\end{array}$ & $\begin{array}{l}\text { History of } \\
\text { psychologi- } \\
\text { cal } \\
\text { disorders }\end{array}$ & $\begin{array}{l}\text { History of } \\
\text { psychologi- } \\
\text { cal } \\
\text { disorders }\end{array}$ & $\begin{array}{l}\text { History of } \\
\text { psychologi- } \\
\text { cal } \\
\text { disorders }\end{array}$ & $\begin{array}{l}\text { History of } \\
\text { psychologi- } \\
\text { cal } \\
\text { disorders }\end{array}$ \\
\hline Yes & $\begin{array}{l}\mathrm{n} \\
\%\end{array}$ & $\begin{array}{l}16 \\
15.4\end{array}$ & $\begin{array}{l}88 \\
84.6\end{array}$ & $\begin{array}{l}104 \\
100\end{array}$ & 53.283 & $<0.001$ \\
\hline No & $\begin{array}{l}\mathrm{n} \\
\%\end{array}$ & $\begin{array}{l}199 \\
2.9\end{array}$ & $\begin{array}{l}6654 \\
97.1\end{array}$ & $\begin{array}{l}6853 \\
100\end{array}$ & & \\
\hline $\begin{array}{l}\text { History of } \\
\text { urinary } \\
\text { tract } \\
\text { infection }\end{array}$ & $\begin{array}{l}\text { History of } \\
\text { urinary } \\
\text { tract } \\
\text { infection }\end{array}$ & $\begin{array}{l}\text { History of } \\
\text { urinary } \\
\text { tract } \\
\text { infection }\end{array}$ & $\begin{array}{l}\text { History of } \\
\text { urinary } \\
\text { tract } \\
\text { infection }\end{array}$ & $\begin{array}{l}\text { History of } \\
\text { urinary } \\
\text { tract } \\
\text { infection }\end{array}$ & $\begin{array}{l}\text { History of } \\
\text { urinary } \\
\text { tract } \\
\text { infection }\end{array}$ & $\begin{array}{l}\text { History of } \\
\text { urinary } \\
\text { tract } \\
\text { infection }\end{array}$ \\
\hline Yes & $\begin{array}{l}\mathrm{n} \\
\%\end{array}$ & $\begin{array}{l}97 \\
6.2\end{array}$ & $\begin{array}{l}1467 \\
93.8\end{array}$ & $\begin{array}{l}1564 \\
100.0\end{array}$ & 65.226 & $<0.001$ \\
\hline No & $\begin{array}{l}\mathrm{n} \\
\%\end{array}$ & $\begin{array}{l}118 \\
2.2\end{array}$ & $\begin{array}{l}5275 \\
97.8\end{array}$ & $\begin{array}{l}5393 \\
100.0\end{array}$ & & \\
\hline Constipation & Constipation & Constipation & Constipation & Constipation & Constipation & Constipation \\
\hline Yes & $\begin{array}{l}\mathrm{n} \\
\%\end{array}$ & $\begin{array}{l}38 \\
9.0\end{array}$ & $\begin{array}{l}385 \\
91.0\end{array}$ & $\begin{array}{l}423 \\
100.0\end{array}$ & 52.181 & $<0.001$ \\
\hline No & $\begin{array}{l}\mathrm{n} \\
\%\end{array}$ & $\begin{array}{l}177 \\
2.7\end{array}$ & $\begin{array}{l}6354 \\
97.3\end{array}$ & $\begin{array}{l}6531 \\
100.0\end{array}$ & & \\
\hline
\end{tabular}

Table 3. The Relationship Between Family Traits and Child's Urinary Incontinence Problem

\begin{tabular}{|c|c|c|c|c|c|c|}
\hline $\begin{array}{l}\text { Family } \\
\text { Traits }\end{array}$ & $\begin{array}{l}\text { Family } \\
\text { Traits }\end{array}$ & $\begin{array}{l}\text { Urinary } \\
\text { Incontinence } \\
\text { Problem }(+)\end{array}$ & $\begin{array}{l}\text { Urinary } \\
\text { Incontinence } \\
\text { Problem (-) }\end{array}$ & Total & Chi-square & $\mathbf{p}$ \\
\hline $\begin{array}{l}\text { Family } \\
\text { income }\end{array}$ & $\begin{array}{l}\text { Family } \\
\text { income }\end{array}$ & $\begin{array}{l}\text { Family } \\
\text { income }\end{array}$ & $\begin{array}{l}\text { Family } \\
\text { income }\end{array}$ & $\begin{array}{l}\text { Family } \\
\text { income }\end{array}$ & $\begin{array}{l}\text { Family } \\
\text { income }\end{array}$ & $\begin{array}{l}\text { Family } \\
\text { income }\end{array}$ \\
\hline level & level & level & level & level & level & level \\
\hline Low & $\begin{array}{l}\mathrm{n} \\
\%\end{array}$ & $\begin{array}{l}256 \\
13.3\end{array}$ & $\begin{array}{l}1662 \\
86.7\end{array}$ & $\begin{array}{l}1918 \\
100.0\end{array}$ & 49.902 & $<0.001$ \\
\hline Middle & $\begin{array}{l}\mathrm{n} \\
\%\end{array}$ & $\begin{array}{l}385 \\
7.4\end{array}$ & $\begin{array}{l}4812 \\
92.6\end{array}$ & $\begin{array}{l}5197 \\
100.0\end{array}$ & & \\
\hline High & $\begin{array}{l}\mathrm{n} \\
\%\end{array}$ & $\begin{array}{l}63 \\
6.6\end{array}$ & $\begin{array}{l}893 \\
93.4\end{array}$ & $\begin{array}{l}956 \\
100.0\end{array}$ & & \\
\hline $\begin{array}{l}\text { Number of } \\
\text { children } \\
1\end{array}$ & $\begin{array}{l}\text { Number of } \\
\text { children } \\
\mathrm{n} \\
\%\end{array}$ & $\begin{array}{l}\text { Number of } \\
\text { children } \\
23 \\
2.8\end{array}$ & $\begin{array}{l}\text { Number of } \\
\text { children } \\
790 \\
97.2\end{array}$ & $\begin{array}{l}\text { Number of } \\
\text { children } \\
813 \\
100\end{array}$ & $\begin{array}{l}\text { Number of } \\
\text { children } \\
1.958\end{array}$ & $\begin{array}{l}\text { Number of } \\
\text { children } \\
0.581\end{array}$ \\
\hline
\end{tabular}




\begin{tabular}{|c|c|c|c|c|c|c|}
\hline $\begin{array}{l}\text { Family } \\
\text { Traits }\end{array}$ & $\begin{array}{l}\text { Family } \\
\text { Traits }\end{array}$ & $\begin{array}{l}\text { Urinary } \\
\text { Incontinence } \\
\text { Problem (+) } \\
\end{array}$ & $\begin{array}{l}\text { Urinary } \\
\text { Incontinence } \\
\text { Problem (-) } \\
\end{array}$ & Total & Chi-square & $\mathbf{p}$ \\
\hline \multirow[t]{2}{*}{2} & $\mathrm{n}$ & 116 & 3527 & 3643 & & \\
\hline & $\%$ & 3.2 & 96.8 & 100 & & \\
\hline \multirow[t]{2}{*}{3} & $\mathrm{n}$ & 49 & 1729 & 1778 & & \\
\hline & $\%$ & 2.8 & 97.2 & 100 & & \\
\hline \multirow[t]{2}{*}{$4+$} & $\mathrm{n}$ & 27 & 696 & 723 & & \\
\hline & $\%$ & 3.7 & 96.3 & 100 & & \\
\hline
\end{tabular}

Table 4. Urinary Incontinence History of Other Family Members and Presence of Urinary Incontinence Problem in Child

\begin{tabular}{|c|c|c|c|c|c|c|}
\hline $\begin{array}{l}\text { Urinary } \\
\text { Incontinence } \\
\text { History of } \\
\text { Other } \\
\text { Family } \\
\text { Members }\end{array}$ & $\begin{array}{l}\text { Urinary } \\
\text { Incontinence } \\
\text { History of } \\
\text { Other } \\
\text { Family } \\
\text { Members }\end{array}$ & $\begin{array}{l}\text { Urinary } \\
\text { Incontinence } \\
\text { Problem }(+)\end{array}$ & $\begin{array}{l}\text { Urinary } \\
\text { Incontinence } \\
\text { Problem (-) }\end{array}$ & Total & Chi-square & $\mathrm{p}$ \\
\hline $\begin{array}{l}\text { Presence } \\
\text { of Urinary } \\
\text { Inconti- } \\
\text { nence in } \\
\text { Mother }\end{array}$ & $\begin{array}{l}\text { Presence } \\
\text { of Urinary } \\
\text { Inconti- } \\
\text { nence in } \\
\text { Mother }\end{array}$ & $\begin{array}{l}\text { Presence } \\
\text { of Urinary } \\
\text { Inconti- } \\
\text { nence in } \\
\text { Mother }\end{array}$ & $\begin{array}{l}\text { Presence } \\
\text { of Urinary } \\
\text { Inconti- } \\
\text { nence in } \\
\text { Mother }\end{array}$ & $\begin{array}{l}\text { Presence } \\
\text { of Urinary } \\
\text { Inconti- } \\
\text { nence in } \\
\text { Mother }\end{array}$ & $\begin{array}{l}\text { Presence } \\
\text { of Urinary } \\
\text { Inconti- } \\
\text { nence in } \\
\text { Mother }\end{array}$ & $\begin{array}{l}\text { Presence } \\
\text { of Urinary } \\
\text { Inconti- } \\
\text { nence in } \\
\text { Mother }\end{array}$ \\
\hline Yes & $\begin{array}{l}\mathrm{n} \\
\% \\
\mathrm{n} \\
\%\end{array}$ & $\begin{array}{l}26 \\
7.5 \\
189 \\
2.9\end{array}$ & $\begin{array}{l}322 \\
92.5 \\
6420 \\
97.1\end{array}$ & $\begin{array}{l}348 \\
100 \\
6609 \\
100\end{array}$ & 23.475 & $<0.001$ \\
\hline $\begin{array}{l}\text { Presence } \\
\text { of Urinary } \\
\text { Inconti- } \\
\text { nence in } \\
\text { Father }\end{array}$ & $\begin{array}{l}\text { Presence } \\
\text { of Urinary } \\
\text { Inconti- } \\
\text { nence in } \\
\text { Father }\end{array}$ & $\begin{array}{l}\text { Presence } \\
\text { of Urinary } \\
\text { Inconti- } \\
\text { nence in } \\
\text { Father }\end{array}$ & $\begin{array}{l}\text { Presence } \\
\text { of Urinary } \\
\text { Inconti- } \\
\text { nence in } \\
\text { Father }\end{array}$ & $\begin{array}{l}\text { Presence } \\
\text { of Urinary } \\
\text { Inconti- } \\
\text { nence in } \\
\text { Father }\end{array}$ & $\begin{array}{l}\text { Presence } \\
\text { of Urinary } \\
\text { Inconti- } \\
\text { nence in } \\
\text { Father }\end{array}$ & $\begin{array}{l}\text { Presence } \\
\text { of Urinary } \\
\text { Inconti- } \\
\text { nence in } \\
\text { Father }\end{array}$ \\
\hline Yes & $\begin{array}{l}\mathrm{n} \\
\%\end{array}$ & $\begin{array}{l}42 \\
13.8\end{array}$ & $\begin{array}{l}263 \\
86.2\end{array}$ & $\begin{array}{l}305 \\
100\end{array}$ & 121.489 & $<0.001$ \\
\hline No & $\begin{array}{l}\mathrm{n} \\
\%\end{array}$ & $\begin{array}{l}173 \\
2.6\end{array}$ & $\begin{array}{l}6479 \\
97.4\end{array}$ & $\begin{array}{l}6652 \\
100\end{array}$ & & \\
\hline $\begin{array}{l}\text { Presence } \\
\text { of Urinary } \\
\text { Inconti- } \\
\text { nence in } \\
\text { Siblings }\end{array}$ & $\begin{array}{l}\text { Presence } \\
\text { of Urinary } \\
\text { Inconti- } \\
\text { nence in } \\
\text { Siblings }\end{array}$ & $\begin{array}{l}\text { Presence } \\
\text { of Urinary } \\
\text { Inconti- } \\
\text { nence in } \\
\text { Siblings }\end{array}$ & $\begin{array}{l}\text { Presence } \\
\text { of Urinary } \\
\text { Inconti- } \\
\text { nence in } \\
\text { Siblings }\end{array}$ & $\begin{array}{l}\text { Presence } \\
\text { of Urinary } \\
\text { Inconti- } \\
\text { nence in } \\
\text { Siblings }\end{array}$ & $\begin{array}{l}\text { Presence } \\
\text { of Urinary } \\
\text { Inconti- } \\
\text { nence in } \\
\text { Siblings }\end{array}$ & $\begin{array}{l}\text { Presence } \\
\text { of Urinary } \\
\text { Inconti- } \\
\text { nence in } \\
\text { Siblings }\end{array}$ \\
\hline Yes & $\begin{array}{l}\mathrm{n} \\
\%\end{array}$ & $\begin{array}{l}43 \\
8.1\end{array}$ & $\begin{array}{l}488 \\
91.9\end{array}$ & $\begin{array}{l}531 \\
100\end{array}$ & 48.132 & $<0.001$ \\
\hline No & $\begin{array}{l}\mathrm{n} \\
\%\end{array}$ & $\begin{array}{l}172 \\
2.7\end{array}$ & $\begin{array}{l}6254 \\
97.3\end{array}$ & $\begin{array}{l}6406 \\
100\end{array}$ & & \\
\hline
\end{tabular}

Hosted file 
Table 1.pdf available at https://authorea.com/users/404870/articles/518310-urinerincontinence-screening-involving-6957-middle-school-students-in-the-eski\%CC\% 87 sehi\%CC\% $87 r$-province

\section{Hosted file}

Table 2.pdf available at https://authorea.com/users/404870/articles/518310-urinerincontinence-screening-involving-6957-middle-school-students-in-the-eski\%CC\%87sehi\%CC\% $87 r$-province

\section{Hosted file}

Table 3.pdf available at https://authorea.com/users/404870/articles/518310-urinerincontinence-screening-involving-6957-middle-school-students-in-the-eski $\%$ CC $\% 87$ sehi $\% C C \%$ $87 r$-province

\section{Hosted file}

Table 4.pdf available at https://authorea.com/users/404870/articles/518310-urinerincontinence-screening-involving-6957-middle-school-students-in-the-eski\%CC\% 87 sehi\%CC\% $87 r$-province 